\title{
First documented record of the Stripe-backed Bittern, Ixobrychus involucris (Vieillot, 1823) (Aves, Ardeidae) in Peru
}

\author{
Rachel Kilby, ${ }_{1}^{1}$ Mauricio Ugarte, ${ }^{2}$ Stuart Timson, ${ }^{3}$ Dennys Góngora Romero ${ }^{1}$
}

1 Reserva Ecológica Taricaya, Madre de Dios, Peru. 2 Área de Ornitología, Colección Científica, Museo de Historia Natural, (MUSA) Universidad Nacional San Agustín, Arequipa, Peru. 3 Projects Abroad, United Kingdom.

Corresponding author: Mauricio Ugarte, mugartelewis@gmail.com

\begin{abstract}
We report the sighting and capture of a Stripe-backed Bittern, Ixobrychus involucris (Vieillot, 1823), in the Reserva Ecológica Taricaya, $26 \mathrm{~km}$ northeast of Puerto Maldonado on the margin of the Madre de Dios River, department of Madre de Dios, southeast Peru. This record confirms the presence of the species for the country, likely as a rare austral migrant. There have been 4 undocumented observations in 40 years, all of them restricted to the Madre de Dios department in the extreme southeast of the country.
\end{abstract}

\section{Key words}

Madre de Dios; new record; Reserva Ecológica Taricaya.

\section{Introduction}

The Stripe-backed Bittern, Ixobrychus involucris (Vieillot, 1823), is a small monotypic heron $(28-35 \mathrm{~cm})$ with a disjunct distribution in northern Colombia to Venezuela, Trinidad, Guyana, Suriname, and French Guiana, where its conservation status is unknown. It also occurs in central and southern South America in Bolivia, Paraguay, Uruguay, Argentina, southern Brazil, central Chile, Vagrant have been sighted in northeastern Ecuador and southeastern Peru (Hilty and Brown 1986, Ridgely and Greenfield 2001, Jaramillo 2003, Rodriguez-Mata et. al. 2006, Restall et. al. 2006, Van Perlo 2009, Narosky and Yzurieta 2010, Schulenberg et al. 2010, Martinez-Vilalta 2014, Herzog et. al. 2016, Remsen et al. 2017). In some areas (Chile, Brazil, NE Argentina), this species occurs year-round, but in other areas, it is absent during the austral winter, although little is known about its movements (Hancock and Elliot 1978, Hilty and Brown 1986, Martinez-Vilalta 2014).

Ixobrychus involucris frequents a variety of habitats including freshwater areas with reed beds, sedges, rushes, long grass, rice fields and tropical marshes. Most of its distribution is in the lowlands, but it is also up to 3,500 m, in lakes and mountain streams (Jaramillo 2003, Rodriguez-Mata et. al. 2006, Restall et. al. 2006, Van Perlo 2009, Narosky and Yzurieta 2010, Martínez-Vilalta et al. 2014).

In Peru it is listed as "Hypothetical" (Plenge 2016, 2017), based on 2 previous sightings in the department of Madre de Dios, 1 supported by unpublished photographic evidence (Terborgh et al. 1984, Schulenberg et al. 2010, Plenge 2016). Here we confirm the presence of I. involucris in the country as presumably a rare austral migrant. 


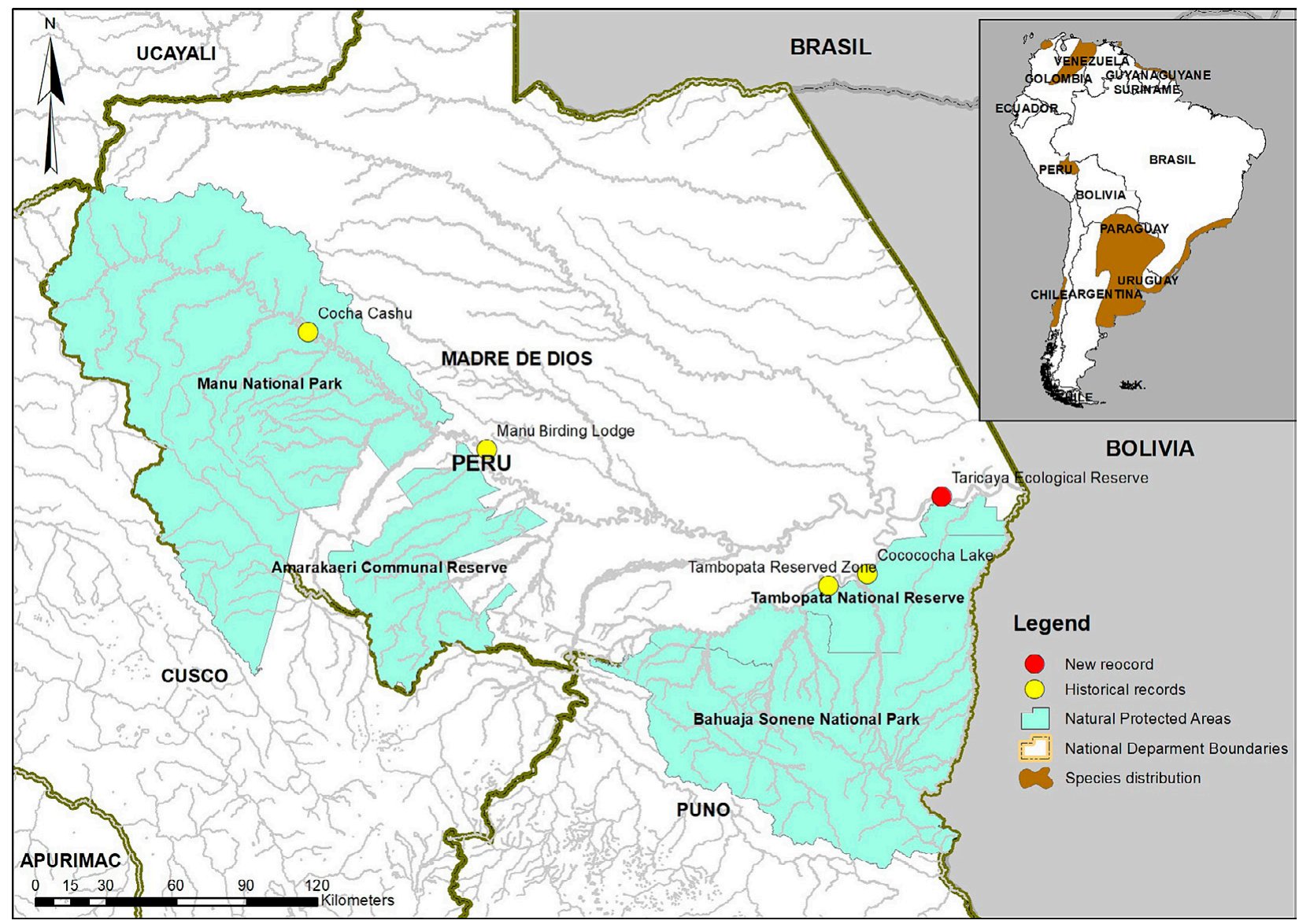

Figure 1. Map of undocumented sightings (yellow circles) of Ixobrychus involucris and the new record (red circle) in Peru. Map inset outlines the species distribution in dark green (NatureServe 2016).

\section{Methods}

We collected an individual of I. involucris (Fig. 1) in the Reserva Ecológica Taricaya (department of Madre de Dios, Peru, where the main habitat is a seasonally flooded forest (Schulenberg et al. 2010).

The bird was captured by hand and kept for observation as it was stunned from a collision with a building, but the bird later died. The specimen, a study skin prepared by Juan Molina, was deposited in the scientific collection of the ornithology section of the Museo de Historia Natural de la Universidad Nacional San Agustín de Arequipa, Peru.

\section{Results}

New record. Peru: department of Madre de Dios: on right bank of the Madre de Dios river: lodge area of the Reserva Ecológica Taricaya, $26 \mathrm{~km}$ NE of Puerto Maldonado $\left(12.5189^{\circ} \mathrm{S}, 068.9800^{\circ} \mathrm{W}\right.$; WGS 84; $175 \mathrm{~m}$ elev.), Rachel Kilby, 22 May 2015 at 21:30 h (1 female, age undetermined, study skin, MUSA 5403) (Fig. 1).

Identification. We identified the individual as I. involucris, which is unmistakable by its small size, the presence of a black stripe along the crown, the heavy black streaking along the back, white streaking on throat and chest, and the distinctive wing pattern with rufous outer flight feathers (Fig. 2) (Schulenberg et al. 2010, MartinezVilalta et al. 2014). Because of these field marks, we immediately discounted the 13 other species of ardeids occurring in the area (Ugarte et. al. unpubl.). The other species of Ixobrychus known from Peru, I. exilis (Gmelin, 1789) (Least Bittern), differs by having a solid black (in males) or chestnut back and rufous on the sides of the head and back of the neck (in females); I. exilis inhabits mostly the Pacific coast and northern Amazonia, with scarce records in southeastern Peru (Schulenberg et al. 2010).

The specimen was found to be a non-reproductive female with undeveloped ovaries, but its age was not determined due to conflicting bibliographical information. The specimen showed no active molt or molt limits and had apparent adult structural characteristics in the plumage (North American Banding Council 2001). Herzog et. al. (2016) noted that the plumage described above is the immature stage, while other authors have not described differences in the plumage coloration between ages (Schulenberg et al. 2010, Martinez-Vilalta et al. 2014).

We obtained the following biometric data from the specimen: wing length $116.0 \mathrm{~mm}$, tarsus length $45.7 \mathrm{~mm}$, tail length $63.0 \mathrm{~mm}$, and bill length (from nares) $31.2 \mathrm{~mm}$.

\section{Discussion}

To our knowledge, this is the second documented sight record of I. involucris in Peru, but the only one based on 


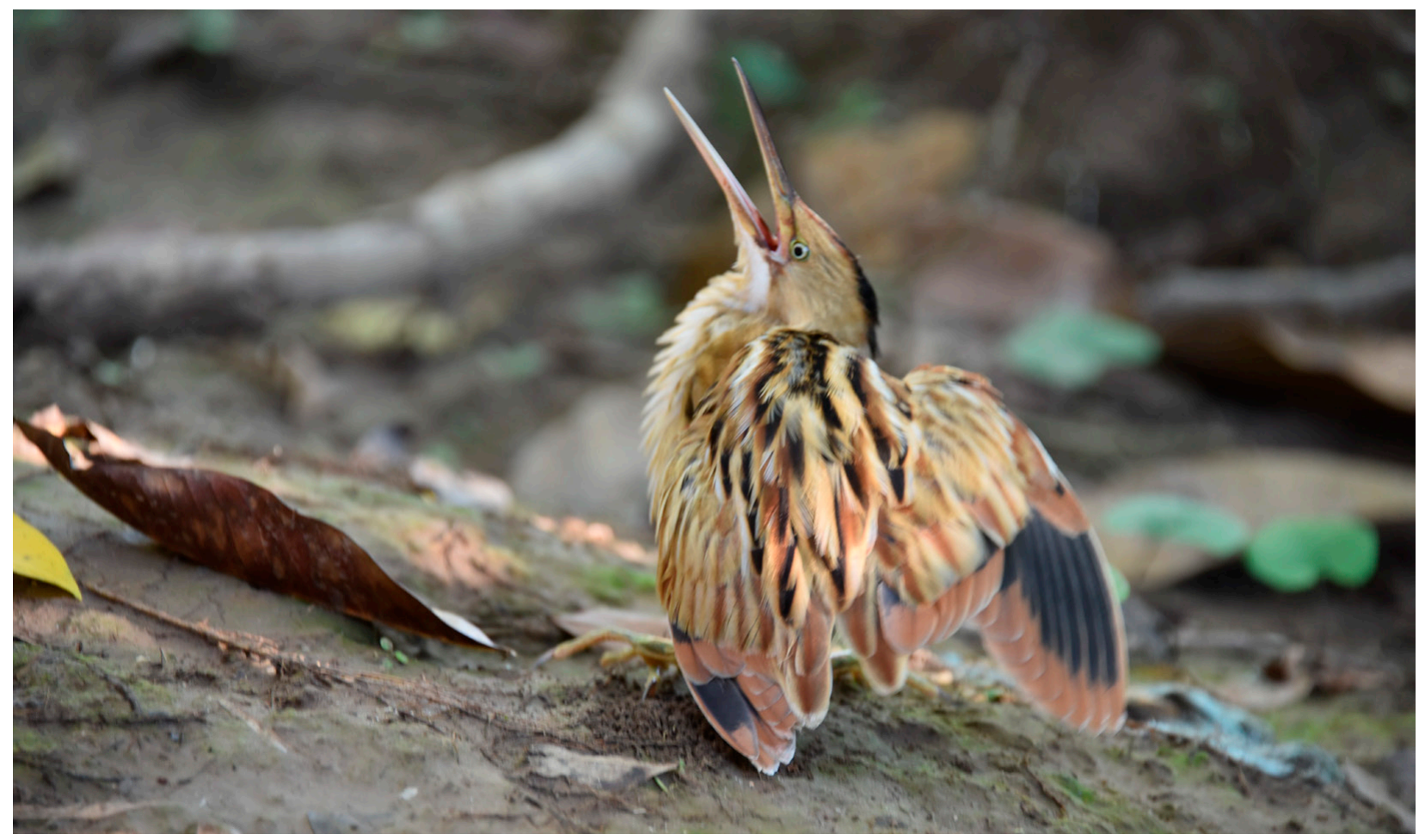

Figure 2. Ixobrychus involucris (MUSA 5403), non-reproductive female captured after it was stunned from a collision with a building in the lodge area of the Reserva Ecológica Taricaya, department of Madre de Dios, Peru.

photographic evidence and a vouchered specimen. There were previously 4 undocumented sightings, all in the department of Madre de Dios. Plenge (2016) mentioned 2 sightings, the first in Cocha Cashu in October 1976 (Terborgh et al. 1984) in Manu National Park and the second in the former Tambopata Reserved Zone (date unknown) by D.A. Scott. The other 2 sightings were reported by Jesus Cieza (pers. comm.) in August 2013 on the right margin of Lago Cocococha, also in the Tambopata area (pers. comm.) and the most recent one by Fernando Angulo (pers. comm.) on 3 December 2016, in a small oxbow lake in Manu Birding Lodge on the left bank of the upper Madre de Dios river.

The location of all the observations in extreme southeast of the country might indicate that these birds originated from populations in the southern part of the continent. It is also possible that the northern part of the population are year-round residents, while the other populations are migrants (Hancock 1978).

Therefore, it is most likely that $I$. involucris is an austral migrant in Peru, based on the time of year; most sightings were between May and October, during the austral winter (Schulenberg et al. 2010). This species has also not been recorded from some breeding areas of the southern population during this period (Martinez-Vilalta et al. 2014).

Based on our new record and this hypothesis, we believe that $I$. involucris should be added to the official list of birds of Peru. With just 3 reported sightings in Peru in the last 40 years, I. involucris should be considered a rare migrant in the country (Schulenberg et al. 2010).

\section{Acknowledgements}

We thank Fernando Angulo, Víctor Gamarra, Manuel Plenge, and Daniel Ramos for information and early comments on the manuscript and Jesús Cieza for information about his sighting of I. involucris. We also thank the staff and volunteers of the ornithology section of the Museo de Historia Natural de la Universidad Nacional San Agustín de Arequipa, but especially Juan Molina. We would like to thank the reviewers for their detailed comments and suggestions on the manuscript.

\section{Authors' Contributions}

RK and DGR conducted the fieldwork; MU, RK and ST wrote the paper; MU studied the specimen.

\section{References}

Hancock J, Elliot H (1978) The Herons of the World. London Editions, London/ Harper and Row Publishers, New York, 304 pp.

Herzog SK, Terrill RS, Jahn AE, Remsen JV Jr, Maillard ZO, GarciaSolíz VH, MacLeod R, Maccormick A, Vidoz JQ (2016) Birds of Bolivia, Field Guide. Asociación Armonía, Santa Cruz de la Sierra, Bolivia, 492 pp.

Hilty SL, Brown WL (1986) A Guide to the Birds of Colombia. Princeton University Press, Princeton, New Jersey, 836 pp.

Jaramillo A (2003) Birds of Chile. Princeton University Press, Princeton, New Jersey, 240 pp.

Martinez-Vilalta A, Motis A, Kirwan GM (2014) Stripe-backed Bittern (Ixobrychus involucris). In: del Hoyo J, Elliott A, Sargatal J, Christie DA, de Juana E (Eds) (2014) Handbook of the Birds of the World Alive. Lynx Edicions, Barcelona. http://www.hbw.com/ node/52720 Accessed on: 2015-06-07.

North American Banding Council (2001) The North American Band- 
ers' Manual for banding Passerines and Near Passerines (Excluding Hummingbirds and Owls). North American Banding Council, Point Reyes Station, California, 15 pp.

Narosky T, Yzurieta D (2003) Guía para la identificación de las aves de Argentina y Uruguay. Aves Argentinas, Vazquez Manzini Editores, Buenos Aires, 346 pp.

Natureserve (2016) NatureServe Web Service. Arlington, Virginia. http://services.natureserve.org. Accessed on: 2016-7-21.

Plenge MA (2016) Species and Subspecies of the Birds of Peru. https:// sites.google.com/site/boletinunop/subespecies. Accessed on: 2016 7-21.

Plenge MA (2017) Lista de las Aves de Perú. Lima, Peru. https://sites. google.com/site/boletinunop/checklist. Accessed on: 2017-01-16.

Remsen, JV Jr, Areta JI, Cadena CD, Claramunt S, Jaramillo A, Pacheco JF, Pérez-Emán J, Robbins MB, Stiles FG, Stotz DF, Zimmer KJ (2017) A classification of the bird species of South America. American Ornithologists' Union. http://www.museum.lsu.edu/ Remsen/ SACCBaseline.htm Accessed on: 2017-12-1.

Restall R, Rodner C, Lentino M (2006) Birds of Northern South
America: an Identification Guide. Vol. 1. Yale University Press, New Haven, 880 pp.

Ridgely RS, Greenfield PJ (2001) The Birds of Ecuador: Volume 1: Status, Distribution, and Taxonomy. Comstock Publishing Associates, Ithaca, NY, $810 \mathrm{pp}$.

Rodriguez Mata J, Erize F, Rumboll M (2006) Birds of South America. Non-passerines: Rheas to Woodpeckers, Harper Collins, London, 384 pp.

Schulenberg TS, Stotz DS, Lane DF, O’Neill JP, Parker TA III (2010) Birds of Peru. Revised and updated edition. Princeton University Press, Princeton, New Jersey, 664 pp.

Terborgh JW, Fitzpatrick FW, Emmons L (1984) Annotated checklist of bird and mammal species of Cocha Cashu Biological Station, Manu National Park, Peru. Fieldiana: Zoology (New Series) 21: i-v, 1-29.

Van Perlo B (2009) A Field Guide to the Birds of Brazil. Oxford University Press, New York, 465 pp.

Vieillot LJP (1823) Tableau Encyclopédique et Méthodique des Trois Règnes de la Nature. Ornithologie 93: 1427 pp. 